\title{
Information literacy, research, scholarship and publication: Comparative of PhD students in Nigerian and South African universities
}

Oyewo Adetola Elizabeth ollytola@yahoo.com University of Kwazulu-Natal, Durban, South Africa

\section{Samuel Umoh Uwem} samum0800@gmail.com South Africa

\begin{abstract}
Public university libraries and ICTs are crucial in teaching, learning and research activities of both Universities and PhD students. PhD student's research matters for academic growth and university ranking. Unfortunately, PhD student's access to ICTs and library facilities in developing countries like Nigeria, is not encouraging, while universities libraries and ICTs are still struggling to fulfill their mandate unlike what is obtainable in developing countries. Plausible reasons include erratic power supply, librarian's attitude and poor ICT skills, inadequate computerization, inadequate infrastructure and human capacity. The resultant effect of this is on student research, access to information for scholarship and publishing opportunities. The paper examines the level information Literacy in terms of ICTs, and library facilities use by PhD students, and its implication on their research, scholarship and publication opportunities. The research was carried out by qualitative research method in public universities in Nigeria and South Africa. A random sampling technique was used to select 40 Nigerian students enrolled at the University of Lagos, Nigeria and University of Kwazulu-Natal, South Africa. The study however, adopts descriptive method of data analysis. Preliminary data reveals that Nigeria students enrolled at the University of KwaZulu-Natal had upper hand in terms of information literacy, research, scholarship and publication than students at the University of Lagos, because of availability and accessibility to ICTs and efficient University library.
\end{abstract}

KEYWORDS: PhD Students. Universities. Information Literacy. Library. Research. Publication. South Africa. Nigeria. 


\section{INTRODUCTION}

Public university and its resources such as libraries and ICTs are crucial in teaching, learning and research activities of both Universities and PhD students. The need for information literacy is crucial amongst PhD students who constitute adult learners that utilize information for thesis writing, publication and in their research in the face of voluminous information in internet age. The PhD also known as a doctoral degree falls under the post graduate education. Postgraduate provision consists of honors, masters and doctoral degrees .A doctoral degree requires a candidate to undertake research at the most advanced academic level, culminating in the submission, assessment and acceptance of a thesis (SOUTH AFRICA DEPARTMENT OF EDUCATION, 2007).

Seehole (2011) notes that doctoral education is the core of university research capacity, source of research productivity and innovation in the global knowledge economy. He added further that doctoral education is expected to produce new, cutting-edge and original ideas and knowledge, through research and exchange of ideas, knowledge and information between professors, researchers and students. PhD students are involved in research that entails thesis writing and publications in journals and conference. In carrying out these activities, they have to sift out information from varied sources such as the internet, electronic resources, libraries, media and other sources in unfiltered form (ACRL,2016). Writing up and publishing research results are crucial for progressing scientific thought and reaching a broad audience (DERNTL,2014). Jasus (2006) opine that information literacy concept evolved from several basic library concepts such as 'library instructions', 'bibliographic education', 'user education', and 'information literacy programmes'. The Society for College, National and University Libraries (SCONUL-2012) defines an informed literate individual as an individual that demonstrates an awareness of how to gather, use, manage, synthesize and create information and data in an ethical manner and will have the information skills to do so effectively. Information literacy is a set of abilities that enhances individuals to recognize when information is needed and have the ability to locate, evaluate, and use effectively the needed information(THE AMERICAN LIBRARY ASSOCIATION-ALA, 2000; 2016; PRESIDENTIAL COMMITTEE ON INFORMATION LITERACY, 1989). Information literacy is the use of information in creating new knowledge and communicate it in an ethical manner (ASSOCIATION OF COLLEGE AND RESEARCH LIBRARIES, 2016; UK CHARTERED INSTITUTE OF LIBRARY AND INFORMATION PROFESSIONALS, 2016).

PhD student enhance institution prestige as a result of research and knowledge production (ALTBACH; REISBERG, 2013; VARGHESE, 2009; 2008; ALTBACH; KNIGHT, 2007). In attaining the objectives of information literacy in the step of building lifelong learners, higher institutions, supervisors and librarians are playing crucial roles in shaping informed literate students and citizens. Altbach (2013) emphasized that aspects of academia such as communications and networks, journals, libraries, informal communities of scholars, conferences and professional organizations, the internet, repositories of knowledge, research universities as critical centres as key to research universities. It is in recognition of the importance of the roles of information literacy in its contributions to lifelong learners, that governments and industries around the world are challenging 
higher institutions systems to emphasize information literacy in their curriculum(ACRL, 2016; JIN; SCHNELLER; ROCHE, 2015; MCTAVISH, 2009).

Information literacy forms the basis of lifelong learners, extends learning beyond formal learning and self directed learning, thus augments students competency learning and sharpen literacy and critical skill(ACRL,2016). Yang, Schneller and Roche(2012) buttress that learning is crucial for the achievement of certain labour market positions in the face of changing working environment, requiring proactive and adaptation of individuals knowledge, capacities and competences. With this view, the study is imperative because of information proliferation in the internet era, students seems to be versatile in the use of social media as face book, twitter to mention but a few but arguably are deficient in information literacy. While it cannot be ignored that students cannot learn everything during the undergraduate study. This has resulted in information literacy deficiency that results into copy-pasting also referred to as 'plagiarism' which seems to be rife amongst students (MCGREGOR; STREITENBERGER, 2004).

\section{RESEARCH OBJECTIVE}

A central focus of the study is to:

- To identify and discuss the 'push' and 'pull' factors that influenced students to University of Kwazulu-Natal(UKZN) and University of Lagos(Unilag) as institutional choice of PhD study.

- To identify university's tools, strategies and resources that enhances information literacy of PhD students.

\section{LITERATURE REVIEW}

The paper is discussed around themes as university, information literacy, $\mathrm{PhD}$. These concepts are explained in this section for better understanding.

\section{CONCEPT OF UNIVERSITY}

Universities falls under higher education that usually occurs after the completion of secondary education. Universities promotes research for the development, use of new technologies, provision of technical and vocational training, entrepreneurship education and programmes for lifelong learning (YANG; SCHNELLER; ROCHE, 2012; UNESCO, 2009). Yang, Schneller and Roche (2012) highlights that different types of institutions have diverse mandates and address different types of learners; respond to and anticipate societal needs. Within the ambit of this paper, the University of KwaZulu-Natal (UKZN) and University of Lagos was the research setting for the paper.

\section{UNIVERSITY OF KWAZULU-NATAL (UKZN)}

The University of KwaZulu-Natal (UKZN) was established on January 1, 2004 as a merger between University of Natal and University of Durban, Westville. It 
has five campuses located in Durban, Westville, Pinetown, Howard, Pietermaritzburg and Kwazulu-Natal. UKZN has a sizeable number of PhD students referred to as 'international students'. Preesha, Rubeshan and Sadhasivan (2011) define an international student as an individual who has relocated to another country mainly for study purposes. Gubba (2014) point out that the University of KwaZulu-Natal (UKZN) is one of the top receiving universities in South Africa's universities with top number of international students estimated at 2, 229 as at 2009. Other top universities in South Africa are Cape Town University with estimated number of international students in 2009 at 4, 423, University of Pretoria, 3,008; Stellenbosch university $(2,731)$, and Witswaterand $(2,159)$. International students from Southern African Development Community (SADC) region; and other African countries as Ghana, Ivory Coast, Kenya, Nigeria and Cameroon are enrolled in the PhD study in South Africa universities (CHRISTOPHER; EFE, 2012; ADEPOJU, 2004).

\section{UNIVERSITY OF LAGOS}

Nigeria has about 108 universities with the classification of first generation university, second generation university and third generation university. The university of Lagos popularly known as 'Unilag' is a federal government research university in Lagos State, South-western Nigeria. The demand for and increase in $\mathrm{PhD}$ enrolment is increasing as the Nigeria University Commission (NUC) mandated that every university lecturer in Nigeria must obtain a doctorate degree before rising to the rank of a senior lecturer and supervising PhDs. The NUC pointed out that there were about 35,000 lecturers in Nigeria and 21,350 of them $(61 \%)$ who still did not have a doctorate degree.

\section{CONCEPT OF PHD}

The $\mathrm{PhD}$ also known as a 'doctoral degree' requires a candidate to undertake research at the most advanced academic level, culminating in the submission, assessment and acceptance of a thesis (SOUTH AFRICA DEPARTMENT OF EDUCATION, 2007). PhD dissertation is the ultimate academic product in a doctoral programme, that showcases its author's training in terms of technical, analytical and writing skills he or she imbibed during the programme (AGU; OMENYI; ODIMEGWU, 2015).Cloete, Sheppard and Bailey(2015) observes that in terms of doctoral production internationally, two groups emerge. The first includes South Korea, Singapore, Taiwan and Mexico acknowledged members leaders in the knowledge economy, and all countries where doctoral output is already high. The second group includes the BRICS countries (Brazil, Russia, India, China and South Africa).

The Green paper on Higher education (2012) stated that in 1995, South Africa produced 679 doctoral graduates, 967 in 2000, 1188 in 2005 and 1420 graduates by 2010 (or 26 doctorates per million of the country's total population). It stated further that the number of Africans has likely been boosted by the increased numbers of international students from other African countries. (120\%). South African enrolments increased from 5117 to 9152 (a growth of 
79\%). This compared to an increase from 975 to 4698 (382\%) among all international students and, within this, enrolments among students from the rest of Africa increased from 573 to 3901 (581\%). The benefits of PhD students are numerous to both the host country and higher institutions. At institutional level, $\mathrm{PhD}$ students are involved in research. Such research is "crucial in nurturing a national intellectual culture, generating high-level discipline-specific human resources, and innovation" (WHITE PAPER, 1997). Research is iterative and depends upon asking increasingly complex or new questions whose answers in turn develop additional questions or lines of inquiry in any field (ACRL, 2016).On parallel line, international PhD student enrolments balance schools' academic budgets; serve as graduate teaching and research assistants; improves the quality and cultural composition of the student body ; enhance institution prestige as a result of research and knowledge production (ALTBACH; REISBERG, 2013; MACGREGOR; VARGHESE, 2009; 2008; ALTBACH; KNIGHT, 2007).

\section{CONCEPT OF INFORMATION LITERACY AND INFORMATION NEEDS OF PHD STUDENTS}

PhD students indulge in research that contributes to knowledge. Thus in the course of the PhD study, information literacy is especially vital for PhD students in accessing information for publishing, research, literature review, conference, evaluation of literature materials, grants and application .They have to sift out information from varied sources such as the internet, electronic resources, libraries, media and other sources in unfiltered form (ACRL,2016; AMERICAN LIBRARY ASSOCIATION, 2000).

Information possesses several dimensions of value, as a commodity, as a means of education, as a means to influence, and as a means of negotiating and understanding the world (ACRL, 2016). Information literacy instruction in higher education can take a variety of forms such as stand-alone courses or classes, online tutorials, workbooks, course-related instruction, or course-integrated instruction (Miller; Chabot and Messina ,2009). Writing a thesis involves writing and publication which enhances students processing information and constructing knowledge (LI; LIM, 2008; CHU et al., 2008). Derntl (2014) buttress that publishing research results is an integral part of a researcher's professional life and that getting a paper published can be a very tedious and time-consuming process especially for early career and novice PhD student.

Secker, Macrae-Gibson and Rowena (2011) points out that the notion of a 'Google generation' has inculcated ingrained coping behaviour in students that students rely heavily on internet search engines. Being exposed to a great deal of information will not make people informed citizens; they need to learn how to use this information effectively (ACRL, 2000). Secker et al. (2011) highlighted the need for information literacy training and support for doctoral level students because they struggle with finding, managing and evaluating information The authors also emphasized the importance of embedding information literacy into the curriculum and teaching it within the context of a discipline are often the key to success in information literacy programmes. 
of computer literacy, library skills, and "a broader, critical conception of holistic approach to information literacy. These include:

- Tool literacy: This is the ability to understand and use the practical and conceptual tools of current information technology relevant to education and the areas of work and professional life that the individual expects to inhabit.

- Resource literacy: This is the ability to understand the form, format, location and access methods of information resources, especially daily expanding networked information resources.

- Social-structural literacy: This is understanding how information is socially situated and produced.

- Research literacy: This is the ability to understand and use the IT-based tools relevant to the work of today's researcher and scholar.

- Publishing literacy: This is the ability to format and publish research and ideas electronically, in textual and multimedia forms ... to introduce them into the electronic public realm and the electronic community of scholars.

- Critical literacy: This is or the ability to evaluate critically the intellectual, human and social strengths and weaknesses, potentials and limits, benefits and costs of information technologies

The Association of College and Research Libraries (ACRL), a division of the American Library Association (ALA-2016), highlight information literate competent individual:

- Formulate questions for research based on information gaps or on reexamination of existing, possibly conflicting, information;

- Use various research methods, based on need, circumstance, and type of inquiry;

- Monitor gathered information and assess for gaps or weaknesses;

- Synthesize ideas gathered from multiple sources;

- Cite the contributing work of others in their own information production;

- Contribute to scholarly conversation at an appropriate level, such as local online community, guided discussion, undergraduate research journal, conference presentation/poster session;

- Critically evaluate contributions made by others in participatory information environments;

- Identify the contribution that particular articles, books, and other scholarly pieces make to disciplinary knowledge;

- Summarize the changes in scholarly perspective over time on a particular topic within a specific discipline;

- Consider research as open-ended exploration and engagement with information;

- Value intellectual curiosity in developing questions and learning new investigative methods;

- Follow ethical and legal guidelines in gathering and using information; 
- Use research tools and indicators of authority to determine the credibility of sources, understanding the elements that might temper this credibility.

\section{RESEARCH METHODOLOGY}

An interpretivist paradigm qualitative research approach and a Case study was utilized for the study. The research setting for the study was at the Howard and Edgewood campus, University of KwaZulu-Natal (UKZN) and University of Lagos (Unilag). Purposive convenience sampling was utilized to select 20 Nigerian participants referred to as 'international students 'studying at Howard and Edgewood campus, UKZN. While 20 participants were also selected at the University of Lagos (Unilag). The other avenues for the sample sampling was through students UKZN email portal platform, Google forms, referrals and personal contacts. The research method views the perspectives of PhD's experiences from the narrative angle. The data collection was through interviews, and focus group. In addition to the secondary source-based research, interviews were conducted with 1st year students during 2015 second semester academic calendar. The first section covered participants demographic backgrounds such as age bracket, marital status, educational level, mode of study, course of study and permit status. Section B covered questions to solicit information on their experience in Unilag and UKZN on the following:

- What are the 'push' and 'pull' factors that influenced students to UKZN and Unilag as an institutional choice of study amongst PhD students?

- To identify university's tools, strategies and resources that enhances information literacy of PhD students.

\section{DEMOGRAPHIC PROFILES}

In terms of migrant Status, the students are on study permit $(n=14)$; Work Permit $(n=3)$ and Asylum permit $(n=3)$

In terms of age bracket, they fall within the age bracket 25-32, 32-39 and 3946 years bracket.

Educational status prior to coming to South Africa: Masters level :( $n=13)$, Diploma level:( $n=2)$ and Honors $(n=5)$

Mode of study: Full Time $(n=25)$, Part Time $(n=15)$

Marital Status: Married $=(n=15)$,Single $(n=17)$, Engaged $(n=8)$

\section{FINDINGS}

On 'push' and 'pull' factors that influenced students to UKZN and Unilag as an institutional choice of study amongst PhD, the following themes emerged: 


\begin{tabular}{|c|c|c|}
\hline Questions & UKZN & Unilag \\
\hline $\begin{array}{l}\text { PhD study } \\
\text { mode }\end{array}$ & $\begin{array}{l}\text { PhD study mode is by research; } \\
\text { Research mode entails writing the } \\
\text { thesis and communicating with } \\
\text { supervisor through mail PhD can } \\
\text { attend weekend and } \\
\text { seminars/workshop; } \\
\text { PhD is ICT based and communication } \\
\text { between PhD student and supervisor } \\
\text { is through mail...contact to see in } \\
\text { person occurs if clarifications and } \\
\text { discussion is to be made. }\end{array}$ & $\begin{array}{l}\text { PhD study mode is by } \\
\text { coursework; } \\
\text { Coursework entails a little bit of } \\
\text { lecture alongside thesis writing; } \\
\text { PhD is still paper based as } \\
\text { students write and submit to } \\
\text { supervisor face-to-face for } \\
\text { corrections/feedback. }\end{array}$ \\
\hline $\begin{array}{l}\text { 'Pull and } \\
\text { Push' Factor } \\
\text { to } \\
\text { institution }\end{array}$ & $\begin{array}{l}\text { Social network as friends and } \\
\text { colleagues gave information on } \\
\text { coming to UKZN...scholarship } \\
\text { especially for full-time students } \\
\text { motivated them coming to UKZN; } \\
\text { The participants agreed that } \\
\text { university ranking might be a key } \\
\text { factor as UKZN as a choice of } \\
\text { institution, but that it does not really } \\
\text { matter based on where they are } \\
\text { coming from. }\end{array}$ & $\begin{array}{l}\text { Reputation and proximity to } \\
\text { home; } \\
\text { For PhD students who are } \\
\text { unwilling to migrate because of } \\
\text { distance, the participants took } \\
\text { advantage of Eramus } \\
\text { programme that allows a PhD to } \\
\text { have two supervisor in } \\
\text { European country and Nigeria } \\
\text { university. }\end{array}$ \\
\hline \multirow[t]{2}{*}{$\begin{array}{l}\text { Numbers of } \\
\text { years for } \\
\text { PhD } \\
\text { completion }\end{array}$} & $\begin{array}{l}\text { The number of years to complete the } \\
\text { programme depends on factors as } \\
\text { supervisor, supervision process, } \\
\text { research topic, funding...You have to } \\
\text { finish the programme by three } \\
\text { years...as a full-time students } \\
\text { because of the of the school fees } \\
\text { waiver, but after three years you pay } \\
\text { continuation fees ...Albeit, the } \\
\text { intellectual property belongs to the } \\
\text { school. }\end{array}$ & $\begin{array}{l}\text { Most of the participants agreed } \\
\text { that to complete a PhD can be } \\
\text { frustrating because there is no } \\
\text { finite number of years to } \\
\text { graduate...you can graduate } \\
\text { within } 7 \text { years or more } \\
\text { depending on supervisors } \\
\text { attitude and examiners; } \\
\text { PhD takes long, leading to } \\
\text { frustration .Delay as a result of } \\
\text { procrastination, 'instead of } \\
\text { correcting your thesis, the } \\
\text { lecturer will say which university } \\
\text { did you go and atimes throw } \\
\text { your thesis write up away'. }\end{array}$ \\
\hline & $\begin{array}{l}\text { You have to publish at least two } \\
\text { papers in journal with your } \\
\text { supervisor before you graduate. }\end{array}$ & $\begin{array}{l}\text { Books published by lecturers are } \\
\text { for profit making and at times } \\
\text { lack peer review...This books are } \\
\text { referred to as self-published } \\
\text { books. }\end{array}$ \\
\hline
\end{tabular}

On university's tools, strategies and resources that enhances information literacy of PhD students. 


\begin{tabular}{|c|c|c|}
\hline & UKZN & Unilag \\
\hline $\begin{array}{l}\text { Workshop, } \\
\text { training } \\
\text { andseminar }\end{array}$ & $\begin{array}{l}\text { UKZN teaching and learning organize } \\
\text { workshop on themes such as 'how to } \\
\text { write an abstract', 'how to publish a } \\
\text { paper' 'how to present at conference' } \\
\text { 'how to develop a poster'; } \\
\text { Participants opined that the } \\
\text { workshop gave information on } \\
\text { predatory journals....publication } \\
\text { opportunity and grants } \\
\text { writing/management. }\end{array}$ & $\begin{array}{l}\text { Students are not really guided } \\
\text { on how research work is to be } \\
\text { carried out at programme } \\
\text { commencement, which merely } \\
\text { serve as a guide on dissertation } \\
\text { writing but does not oral or } \\
\text { written feedback by one. }\end{array}$ \\
\hline $\begin{array}{l}\text { School } \\
\text { factors } \\
\text { affecting the } \\
\text { PhD } \\
\text { Programme }\end{array}$ & $\begin{array}{l}\text { Other factors affect the PhD thesis } \\
\text { and its quality such as, ICT, electricity } \\
\text { and data collection.... PhD students in } \\
\text { UKZN have access to student email } \\
\text { and portal; } \\
\text { Turnitin software for detecting } \\
\text { plagiarism as students are aware of it } \\
\text { and use. }\end{array}$ & $\begin{array}{l}\text { Insufficient educational } \\
\text { facilities such as internet and } \\
\text { ICT connectivity in school which } \\
\text { makes publishing difficult; } \\
\text { Turnitin software is not } \\
\text { effective making copy paste still } \\
\text { rife. }\end{array}$ \\
\hline $\begin{array}{l}\text { How is the } \\
\text { school } \\
\text { library } \\
\text { contributing } \\
\text { to PhD } \\
\text { students } \\
\text { information } \\
\text { literacy }\end{array}$ & $\begin{array}{l}\text { Students allowed to borrow books } \\
\text { credited to their student account } \\
\text { School library and school generally } \\
\text { subscribes to high quality index } \\
\text { journal for PhD student research; } \\
\text { School library has features as } \\
\text { research commons for PhD students; } \\
\text { Library orientations conducted for } \\
\text { first year students at the beginning of } \\
\text { each academic semester, that enable } \\
\text { students to learn more about the } \\
\text { library's collections, resources, } \\
\text { services, and physical set up of the } \\
\text { building; } \\
\text { Students provided with green/yellow } \\
\text { pamphlet providing information on } \\
\text { website and journal resources for } \\
\text { research; } \\
\text { Students serves as library assistant. }\end{array}$ & $\begin{array}{l}\text { Students not allowed to borrow } \\
\text { books but photocopy is allowed. }\end{array}$ \\
\hline Publications & $\begin{array}{l}\text { Opportunities to publish papers is } \\
\text { easy because of ICT, electricity, WIFI } \\
\text { and internet connectivity in school; } \\
\text { Publishing is easy as there is guidance } \\
\text { with senior colleagues and as such } \\
\text { collaboration between peer is } \\
\text { facilitated. }\end{array}$ & $\begin{array}{l}\text { Opportunities to publish papers } \\
\text { is difficult especially for novice } \\
\text { PhD except there is } \\
\text { collaboration with senior } \\
\text { mentor lecturer; } \\
\text { Books published by lecturers are } \\
\text { for profit making and at times } \\
\text { lack peer review...This books are } \\
\text { referred to as self-published } \\
\text { books. }\end{array}$ \\
\hline $\begin{array}{l}\text { Quality of } \\
\text { Lecturer and } \\
\text { supervision }\end{array}$ & $\begin{array}{l}\text { The supervisor-supervisee } \\
\text { relationship is like mentor-mentee; } \\
\text { The participants agreed that } \\
\text { supervisors matters for the PhD } \\
\text { study; } \\
\text { PhD defence usually occurs before }\end{array}$ & $\begin{array}{l}\text { The supervisor-supervisee } \\
\text { relationship is like Boss-servant. } \\
\text { No respect for students. } \\
\text { Lecturers believe they know it } \\
\text { all; } \\
\text { Most lecturers obtained their }\end{array}$ \\
\hline
\end{tabular}




\begin{tabular}{|c|c|c|}
\hline & the PhD commence. & $\begin{array}{l}\text { PhDs (as well as their BSc and } \\
\text { MSc degrees) from that very } \\
\text { same department and also } \\
\text { taught and mentored by senior } \\
\text { colleagues who rose through } \\
\text { the ranks based on publications } \\
\text { in departmental journals; } \\
\text { Lecturers attitudes towards } \\
\text { PhD students is not } \\
\text { encouraging...they alleged the } \\
\text { reason for this behaviour is } \\
\text { because the lecturer that taught } \\
\text { them victimized them so they } \\
\text { have to do same to us... if you } \\
\text { report you might be victimized... } \\
\text { There is no checks and balances } \\
\text { on Nigerian lecturer...Some PhD } \\
\text { students have to resort to been } \\
\text { a lecturer's boy to curry favour; } \\
\text { The candidate has to pay the } \\
\text { cost of scheduling a doctoral } \\
\text { defense (includes transport, } \\
\text { accommodation, per diem for } \\
\text { the External Examiner; and } \\
\text { other incidentals). }\end{array}$ \\
\hline $\begin{array}{l}\text { Fundingand } \\
\text { Scholarship }\end{array}$ & $\begin{array}{l}\text { Funding and grant matters because it } \\
\text { might involve traveling from state to } \\
\text { state, or out of the country, to } \\
\text { gather data and meet scholars } \\
\text { depending on the nature of the } \\
\text { research though; } \\
\text { PhD students in UKZN agreed that } \\
\text { they access bursaries and grants } \\
\text { depending on the department but } \\
\text { that South African PhD students are } \\
\text { prioritize. }\end{array}$ & $\begin{array}{l}\text { No bursaries and grants for PhD } \\
\text { student, but lecturers } \\
\text { wholecture in government } \\
\text { university and pursued PhD } \\
\text { enjoy study leave, scholarship } \\
\text { and bursaries. }\end{array}$ \\
\hline Conference & $\begin{array}{l}\text { Conference are free or at subsidized } \\
\text { rate for PhD students...This also gives } \\
\text { the platform to network with authors, } \\
\text { scholars and other advanced senior } \\
\text { colleagues; } \\
\text { Opportunities to attend conference is } \\
\text { possible because supervisor write } \\
\text { recommendation letter for students. }\end{array}$ & Conference difficult to attend. \\
\hline
\end{tabular}




\section{DISCUSSION}

Albeit, it cannot be ignored that information literacy is an essential component of general education at graduate levels introduced in courses as GST, and library studies as laying the foundation for information literacy to help students to build the necessary skills in accessing information. Although the degree of success of information literacy initiative depends on the instructors and school library. The increase in the number of students migrating in search of PhD according to Whitehead and Sing (2013) that globally, the number of students studying outside their home countries is growing and there has been a shift from almost exclusively South-North mobility to more South-South mobility. Prior to 1994, South Africa had a very small number of international PhD students. The reason for the choice of South Africa as a preferred destination for international PhD students is that South Africa been rated as one of the top ten destinations for foreign students wanting to pursue a degree away from their home countries( TATI, 2010). Altbach(2013) posits that research universities have the potential for significant income generation, but expenditures for adequate salaries for faculty, well-equipped libraries and laboratories, and scholarships for bright but needy students are required.

\section{CONCLUSION}

The need for PhD students to develop information literacy skills is vital to maximize employability and lifelong learning, in addition to reducing attrition rates. The need for information literacy amongst PhD students in accessing information for publishing, research, literature review, conference, evaluation of literature materials, grants application, and conference cannot be over estimated. This is because when students lack information competence and skills, it will be difficult to transfer information to research and daily experience. It is expected that during the PhD process and the end of the programme, such students should be able to communicate research findings ethically through written publication and, at appropriate conferences. In addition to having as indepth understanding of copyright issues and how to get research published. Thus there is still the need for the Nigeria University Commission(NUC) to regulate aspect of academic quality in terms of journals and books. Thus, university should provide rich quality environment for PhD study. 


\title{
Informação, pesquisa, bolsas de estudo e publicação: Comparativo de alunos de doutorado em universidades Nigerianas e Sul-Africanas
}

\begin{abstract}
RESUMO
Bibliotecas universitárias públicas e as TIC (Tecnologia da Informação e Comunicação) são cruciais para atividades de ensino, aprendizagem e pesquisa de ambas as Universidades e para os estudantes de doutoramento. Matéria de investigação para estudante $\mathrm{PhD}$, para o crescimento acadêmico e classificação das universidades. Infelizmente, o acesso do estudante PhD às TIC e instalações da biblioteca em países em desenvolvimento como a Nigéria, não é encorajadora, enquanto as universidades, bibliotecas e TIC ainda estão lutando para cumprir o seu mandato, ao contrário do que se poderia obter em países em desenvolvimento. Razões plausíveis incluem fonte de alimentação irregular, a atitude de bibliotecários e competências em TIC"s pobres, informatização inadequada, infraestrutura inadequada e capacidade humana. O efeito resultante deste está na pesquisa do aluno, o acesso à informação para bolsas de estudo e publicações de oportunidades. $O$ documento examina o nível da informação de Alfabetização em termos de TIC e serviços de bibliotecas por uso de estudantes de doutoramento, e sua implicação em suas oportunidades de pesquisa, bolsas de estudo e publicação. A pesquisa foi realizada pelo método qualitativo de pesquisa nas universidades públicas na Nigéria e África do Sul. A técnica de amostragem aleatória foi usada selecionando 40 estudantes nigerianos matriculados na Universidade de Lagos, na Nigéria e na Universidade de Kwazulu-Natal, África do Sul. O estudo no entanto, adota o método descritivo de análise de dados. Dados preliminares revelam que os alunos da Nigéria matriculados na Universidade de KwaZulu-Natal tinham vantagens em termos de alfabetização da informação, pesquisa, bolsas de estudo e publicação em relação aos estudantes da Universidade de Lagos, por causa da disponibilidade e acessibilidade às TIC e biblioteca de Universidade mais eficiente.
\end{abstract}

PALAVRAS-CHAVE: Os estudantes de doutoramento. Universidades. Alfabetização pela informação. Biblioteca. Pesquisa. Publicação. África do Sul. Nigéria. 


\section{REFERENCE}

ACRL.Information Literacy Competency Standards Review Task Force. "Task ForceThe Information literacy Competency standards for Higher EducationRecommendations." ACRL AC12 Doc 13.1, June 22, 2016.

ADEPOJU, A. Leading Issues in International Migration in Sub-Saharan Africa. In Cross, C, D Gelderblom, N Roux \& J Mafukidze (eds): Views on Migration in SubSaharan Africa. Proceedings. 2006.

ACRL (Association of college and research libraries). 2000. Information Literacy. From: <http://www.ala.org/ala/acrl/>.Accessed: 20/05/2016.

ACRL (Association of college and research libraries.). June 25

AGU; OMENYI; ODIMEGWU.Evaluation of Doctorate Dissertation in Nigerian Universities: Do Faculties Provide and Use Explicit Criteria/Rubrics? International Journal of Technology and Inclusive Education (IJTIE), Volume 4(1). 2015.

ALTBACH, P.;REISBERG, L.; RUMLEY, L.Trends in Global Higher Education: Tracking an Academic Revolution. Report prepared for the UNESCO 2009 World Conference on Higher Education. Paris, UNESCO. 2009.

ALTBACH.August 11, The role of research universities in developing countries University. 2013.

The role of research universities in developing countries.11 August 2013 Issue No:282. From: <www.universityworldnews.com/article.php?story... >. University World News.

AMERICAN LIBRARY ASSOCIATION.Position paper on Information Literacy - AASL. 2000. From: <http://www.fiu.edu/ library/ili/ilicurr.html>. Accessed 16/04/2016.

ASSOCIATION OF COLLEGE \& RESEARCH LIBRARIES.Information literacy competency standards for higher education. 2000. From: <http://www.ala.org/acrl/ilintro.html>. Accessed 05/12/ 2015.

BACKHOUSE, J. Doctoral Education in South Africa:Models, Pedagogies and Student Experience, University of Witwatersand. 2009. 
BHANDARI, R.;BELYAVINA, R.Global Student Mobility: Trends and New Directions, in International higher education .The Boston College CenterFor International Higher Education. Number 66 : Winter, pp.14. 2012.

BUNDY, A.Australian and New Zealand Information Literacy Framework principles, standards and practice, 2nd ed. Adelaid: Australian and New Zealand Institute Information Literacy. (ed.)2004.

CHE.Towards a New Higher Education Landscape: Meeting the equity, quality and social development imperatives of South Africa in the 21st century. Pretoria: Council on Higher Education. 2000.

CHRISTOPHER, I.;ISIKE, E.A Socio-cultural Analysis of African Immigration to South Africa. 2012. Alternation 19,(1 ) 93 - 116 ISSN 1023-1757 93.

CLOETE,N. A new look at demographic transformation: Comments on Govinder et al. South African Journal of Science 110(1/2). 2014.

CLOETE, N.;BAILEY,T.;PILLAY,P.;BUNTING, I.;MAASSEN,P. Universities and Economic Development in Africa.Cape Town: Centre for Higher Education Transformation. 2011.

DE WIT, H.;AGARWAL,P.;SAID, M.;SEHOOLE,M.;SIROZI,M. The dynamics of international student circulation in a global context. Rotterdam: Sense Publishers.(eds.) 2008.

DHET.White Paper for Post- School Education and Training: Building an expanded, effective and integrated post- school system. Pretoria: Department of Higher Education and Training. 2013a.

DHET. Higher Education Management Information System (HEMIS), 2000- 2012. Pretoria: Department of Higher Education and Training. 2013b.

DOE.Education White Paper 3: A programme for the transformation of higher education. General Notice 1196 of 1997. Pretoria: (Former) Department of Education. 1997.

DOE.South African Post- Secondary Education (SAPSE) Information System.Pretoria: Department of EducationGuidelines on Information Literacy have been compiled by the Information Literacy Section (InfoLit) of the International Federation of Library Associations and Institutions (IFLA)(2006). 1999. 
HAYWARD,F.M. Graduate Education in Sub-Saharan Africa, inInternational highereducation. The Boston College Center For International Higher Education. Number 66: Winter,pp.21.2012.

INFORMATION LITERACY Competency Standards for Higher Education | Association of College \& Research Libraries (ACRL). (n.d.). From:

$<$ http://www.ala.org/acrl/standards/informationliteracycompetency $>$. Retrieved: 23/06/2016.

JASUS, L.Guidelines on information literacy for Lifelonglearning. 2006.

JIN, Y.;SCHNELLER,C.;ROCHE, S.The Role of Higher Education in Promoting Lifelong Learning. UNESCO Institute for Lifelong Learning Publication Series on Lifelong Learning Policies and Strategies: No. 3.Feldbrunnenstrasse 5820148 Hamburg Germany. 2015.

LANKSHEAR, C; KNOBEl, M.New Literacies: Changing Knowledge and Classroom Learning. Buckingham: Open University Press. 2003.

MCGREGOR;STREITENBERGER, D.Do Scribes Learn? Copying and Information Use.In M.K..Chelton andC.Cool(Eds.).Youths information-seeking behaviour; theories, models and uses.pp.95-118.Lanham,MD:Scarecow Press. 2004.

MCKENZIE, Jamie.Filling the Tool Box: Classroom Strategies to Engender Student Questioning.1997. From:<http://fromnowon.org/toolbox.htm|\#Class>. Retrieved: $5 / 11 / 2015$

NIGERIA: Urgent need for more academicas with phds.From:

$<$ www.universitttyw/article... > Presidential Committee on Information Literacy: Final Report. January 10, 1989. Retrieved: 25/03/2016.

SECKER, Jane;MACRAE-GIBSON, Rowena.Evaluating MI512: an information literacy course for PhD. 2011.

SHAPIRO, J. J.; HUGHES, K. S.Information Literacy as a Liberal Art. Education Review, 31(2). 1996.

SMITH, L. I. Critical information literacy instruction for the development of political agency.Journal Of Information Literacy, 7(2), pp. 15-32. 2013. 
THOMAS, P. Mackey;TRUDI, E. Jacobson.Metaliteracy: Reinventing Information Literacy to Empower Learners. (Chicago: Neal-Schuman, 2014).

THOMAS,P. Mackey;TRUDI E. Jacobson.Reframing Information Literacy as a Metaliteracy.College and Research Libraries72, no. 1 (2011): 62-78. 2011.

THE GREEN PAPER For Post-School Education And Training (2012).

GUBBA, A.The effects of student migration to South African universities on higher education in Zimbabwe. Unpublished Phd Dissertation, University of South Africa. 2014.

UNESCO.Institute for Education (UIE).The Cape Town Statement on Characteristic Elements of a Lifelong Learning Higher Education Institution. Hamburg: UNESCO.Institute for Lifelong Learning. 2001.

UNESCO.Communiqué of the World Conference on Higher Education: The New Dynamics of Higher Education and Research for Societal Change and Development.Paris: UNESCO. 2009.

WALTERS, S. Higher education in lifelong learning in a middle income country: but by the grace of champions? Slowey, M. and Schuetze, H. (eds), Global Perspectives on Higher Education and Lifelong Learners. London and NY, Routledge. 2012.

WHAT IS THE NFIL?".National Forum on Information Literacy.Retrieved October 25, 2012.

VARGHESE, N.V.;PÜTTMANN, V. Trends in Diversification of Post-secondary Education.Paris, UNESCO. 2011.From:

$<$ http://unesdoc.unesco.org/images/0019/001915/191585e.pdf >.Accessed: 19/09/2014. 
Recebido: 08 abr. 2016.

Aprovado: 26 ago. 2016

DOI: $10.3895 /$ rbpd.v5n1.4554

Como citar: ELIZABETH, O. A.; UWEM, S. U. Information literacy, research, scholarship and publication: Comparative of PhD students in Nigerian and South African universities R. bras. Planej. Desenv.,Curitiba, v. 5, n. 3, p. 458-474, set./dez. 2016. Disponível em: <https://periodicos.utfpr.edu.br/rbpd>. Acesso em: XXX. Correspondência:

Oyewo Adetola Elizabeth

King George V Ave, Durban, 4041, South Africa .

Direito autoral: Este artigo está licenciado sob os termos da Licença CreativeCommons-Atribuição 4.0 Internacional. 